\title{
Egyptian Public's Knowledge, Attitudes, Perceptions, and Practices toward COVID-19 Infection and Their Determinants. A Cross-Sectional Study, 2020
}

\author{
Doaa I. Omar', Samar A. Amer* \\ ${ }^{1}$ Department of Community, Environmental and Occupational Medicine, Benha Faculty of Medicine, Benha University, Banha, \\ Egypt; ${ }^{2}$ Department of Public Health and Community Medicine, Zagazig University, Zagazig, Egypt
}

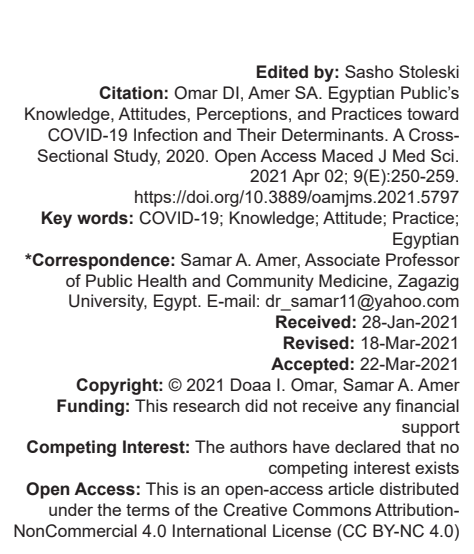

COVID-19 is an emerging respiratory infection; it was first discovered in December 2019, in Wuhan city, China [1]. By the end of January 2020, the World Health Organization (WHO) has announced an international public health emergency and called for the organized, collaborative efforts at all levels worldwide, for prevention and control its spread [2] Later on, declared it as a "global pandemic" [3].

COVID-19 belongs to a wide family of singlestranded RNA viruses that cause illnesses ranging from common cold to severe disease [4]. Most common symptoms are: Fever, dry cough, and fatigue. Less prevalent symptoms: Body aches and pains, sore throat, headache, conjunctivitis, diarrhea, loss of taste or smell, skin rash, or discoloration of fingers or toes. Serious symptoms are: Difficult breathing or shortness of breath, chest pain, and loss of speech or movement [5]. Older people, and those with chronic diseases such as cardiovascular disease, diabetes mellitus, chronic respiratory disease, and cancer are more prone to develop serious illness.

COVID-19, primarily is a droplet infection, so washing hands regularly with soap and water, or hand sanitizer, avoiding touching the face and practicing physical distancing and refrain from smoking or other practices that weaken the respiratory system, are primary preventive measures [6].

No proven effective treatments or vaccines are available to control COVID-19 posing a significant threat to health-care delivery. The best way for prevention and control is raising awareness about the COVID-19 virus and disease [6]. To minimize the spread of the virus and flatten the curves, most nations, including African countries, have applied strict prevention and control measures to curb the disease including regulations such as general lockdown, ban on public gatherings, obligatory home quarantine, international flights restrictions and raising awareness on proper hand wash, hygiene, and sanitation as well as social distancing [7]. 
Egypt is one of the biggest countries in the Arab region, Africa and the Middle East with more than 100 million citizens [8]. Egypt announced the first COVID-19 cases in February 2020, by the beginning of April of 2020, there were over 800 confirmed cases, with more than 50 fatalities [9]. This followed by increase in the number of cases exceeding 91,000 confirmed cases and over 3200 deaths. Low- and middle-income countries in Africa including Egypt, face difficulties in preventing and controlling the spread of the disease due to their inadequate preparedness accompanied by low allocated resources, which could lead to catastrophic consequences [10].

The Egyptian government explore its efforts facing COVID-19 pandemic and declared that work was carried out on 6 axes, which were the application of preventive measures, the ban on the movement of citizens and the limitation of gatherings, the strengthening of medical infrastructure, the provision of strategic supplies and goods, the reduction of the repercussions of "Corona" on the Egyptian citizen and economy, and the return of Egyptian People stranded abroad and media awareness and confronting rumors [11].

In Egypt, the high number of Egyptian citizens could be associated with a great risk of spread and mortality. To slow the spread, minimize the crowd the government enforced a nighttime curfew for 2 weeks starting from the last week of March 2020 and close all restaurants and cafes for the same period of time [12]. The effectiveness of these efforts depends on the public awareness of the COVID-19 infection.

Thus, this study aims to assess the Egyptian public knowledge, attitudes, perceptions, and practices (KAPP) regarding COVID-19, and obstacles they face during the implementation of practices during the pandemic. KAPP is a corner stone to provide better insights to direct the policy and health decision makers toward the weakness points and gaps in knowledge and practice, and the development of preventive strategies and health promotion programs targeting those points. In addition to provide baseline information about the Egyptian society, to determine the type and level of intervention that may be required to change misconceptions, adapt, and implement behavioral changes health measures.

\section{The Methodology}

This cross-sectional study was conducted among the general population of Egypt, from April 15, 2020 , to June 15,2020 . The target population were all the residents of Egypt during the study period, and using internet excluding the Illiterate, COVID-19 cases, and health-care provider (doctor, nurse, pharmacist, technician, dentist, etc.)
The calculated sample size was 385 , at a $95 \%$ confidence level, and $80 \%$ power of the study, with a hypothesis that $50 \%$ of the respondents would have a satisfactory knowledge level of COVID-19. Considering the low response rate of online surveys, the sample size tripled to be 999 participants.

The data collection tool; well-structured, pretested, online self-administered,Arabic questionnaire, prepared based on the $\mathrm{WHO}$ course materials emerging respiratory viruses, including COVID-19: Methods for detection, prevention, response [13]. The questionnaire was validated by two experts and pilot study was done on 15 participants to ensure comprehension and clarity and its results were not included in the study (Appendix).

The questionnaire composed of five main sections as follows in order;

1. Socio-demographic and medical history; age, sex, residence, education, occupation, marital status, smoking history, and presence of chronic disease

2. Knowledge section: Composed of 32 questions (Q) (symptoms; $8 \mathrm{Q}$, mode of transmission: 8 $\mathrm{Q}$, risky groups: $7 \mathrm{Q}$, and knowledge about preventive measures: $9 \mathrm{Q}$ ) and the source of information about COVID-19 infection

3. Attitudes Section: Composed of $4 \mathrm{Q}$ to evaluate attitude. The attitude toward the disease represented by 1 questions, while the attitude toward the available intervention measures was represented by $3 Q$ [14]

4. Perceptions Section: Composed $7 \mathrm{Q}$ to evaluate perceptions, one $Q$ for perceived severity, $2 \mathrm{Q}$ for perceived susceptibility, $2 \mathrm{Q}$ for perceived benefits from intervention, and $1 \mathrm{Q}$ for perceived barriers

5. The practice section was represented by 16 $Q$ to assess the practice during the previous 2 weeks.

N.B; The scoring system; as regard

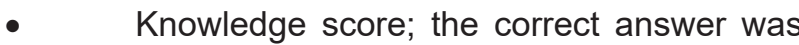
assigned 1 and the incorrect or do not know answer was assigned zero, a higher score indicating better results

- $\quad$ Practice; through a Likert scale, no and rare were assigned as zero. Often and sometimes were assigned as one. Always was assigned as two.

The percentage of the total score of the knowledge, and practice scores were categorized according to bloom's cutoff point, as good if the score was between $80 \%$ and $100 \%$, moderate if the score was between $60 \%$ and $79 \%$, and poor if the score was $<60 \%$ [15]. Using a convenient sampling method, the data were collected through an online self-administered survey portal, Google form was created, and participants were invited to complete and submit the questionnaire, after a written informed consent. The questionnaire was distributed through private Facebook and What's 
App accounts the most famous platforms in Egypt and to increase the response rate, continuous reminder messages were sent.

\section{Statistical analysis}

The data were analyzed using SPSS version 23 , and a level of significance $(p<0.05)$. Qualitative data were presented as frequency and percent, while quantitative data were presented as mean \pm standard deviation (SD). Student's t-test was used to compare the mean between two groups while ANOVA ( $f$ test) was used to compare the mean between more than two groups. Pearson's correlation coefficient $(r)$ was used to test the association between two continuous variables.

\section{Results}

A total of 999 participants were enrolled in the study. $628(62.8 \%)$ were among the age group (20 -< $40 \mathrm{y})$, majority of them $666(66.7 \%)$ were females 576 (57.6) from urban residence, 665 (66.7\%) were married, with $605(60.5 \%)$ university educated or higher, and only 105 (10.5\%) had chronic diseases.

Out of the 999 participants about $97.5 \%$ of participant clearly stated that the symptoms of COVID19 were fever and difficulty of breath, 98\% reported that the virus is typically spread through contact with airborne droplets. As regard the high risk groups, 985 (98.5\%) reported older population, and around $96.6 \%$ reported that chronic diseases and HCWs. A majority of participants about (99.0\%) knew coronavirus can be prevented by implementing measures such as regular handwashing, social distancing, and disinfecting contaminated surfaces (Tables 1 and 2).

The most popular sources of information about COVID-19 infection were social media (64.5\%), followed international and governmental official websites $(12.8 \%)$, family members $(12.4 \%)$, and (TV and radio) (6\%) (Figure 1$)$.

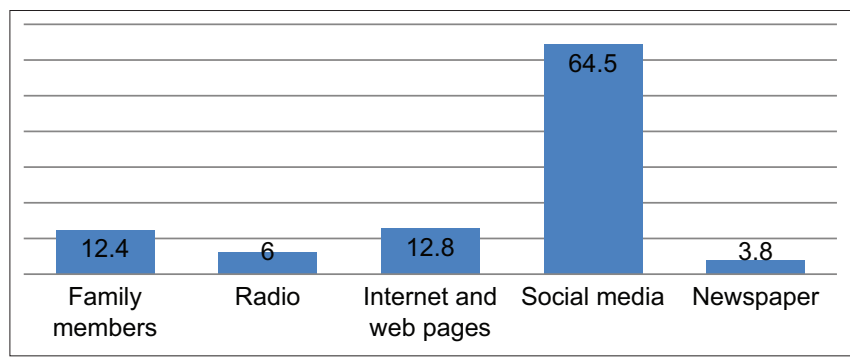

Figure 1: The sources of information about COVID-19 infection among Studied Egyptians

Regarding knowledge of COVID-19 infection; $528(52.8 \%)$ of participants showed good level of knowledge, the average percentage of the overall knowledge score was $80.9 \% \pm 7.1$. The average percentage of knowledge in descending order was knowledge about preventive measures (99.2 \pm 2.3 ), symptoms (88.4 \pm 17.3$)$, risky groups (76.1 \pm 15.2$)$, and the lowest was as the percentage of knowledge about the mode of transmission (54.3 \pm 14.5$)$.

Table 1: The Public's knowledge toward COVID-19 infection

\begin{tabular}{|c|c|c|c|c|c|}
\hline Knowledge variables & No & Don't know & Yes & Total & Total knowledge \\
\hline \multicolumn{6}{|l|}{ Knowledge about the symptoms } \\
\hline Fever & $16(1.6)$ & $8(0.8)$ & $975(97.5)$ & Score $=7.1 \pm 1.30-8$ & Total knowledge score $=25.9 \pm 2.315-32$ \\
\hline Cough & $36(3.6)$ & $40(4.0)$ & $923(92.3)$ & & \\
\hline Difficulty of breath & $16(1.6)$ & $14(1.4)$ & $969(97.0)$ & & \\
\hline Fatigue & $64(6.4)$ & $116(11.6)$ & $819(82.0)$ & & \\
\hline Sore throat & $54(5.4)$ & $40(4.0)$ & $905(90.6)$ & Score percentage $=88.4 \pm 17.3$ & \\
\hline GIT upset (vomiting and diarrhea) & $116(11.6)$ & $130(13.0)$ & $753(75.3)$ & & \\
\hline Loss of smell and taste & $84(8.4)$ & $96(9.6)$ & $819(82.0)$ & & \\
\hline Asymptomatic & $26(2.6)$ & $36(3.6)$ & $937(93.8)$ & & \\
\hline \multicolumn{6}{|l|}{ Knowledge about the mode of transmission } \\
\hline Drople & $12(1.2)$ & $8(0.8)$ & $979(98.0)$ & Score $=4.3 \pm 1.20-8$ & \\
\hline Contact & $16(1.6)$ & $4(0.4)$ & $979(98.0)$ & & \\
\hline Blood born & $163(16.3)$ & $296(29.6)$ & $540(54.1)$ & & \\
\hline Zoonotic & $232(23.2)$ & $305(30.5)$ & $462(46.2)$ & & \\
\hline Food & $197(19.7)$ & $144(14.4)$ & $658(65.9)$ & Score $\%=54.3 \pm 14.5$ & \\
\hline Drink & $253(25.2)$ & $185(18.5)$ & $562(56.3)$ & & \\
\hline Airborne & $221(22.1)$ & 191 (19.1) & $587(58.8)$ & & \\
\hline Indirect contact & $10(1.0)$ & $8(0.8)$ & $981(89.2)$ & & \\
\hline Knowledge about the high risk groups & & & & & Total knowledge $\%=80.9 \pm 7.1(46.8-100.0)$ \\
\hline All community members & $430(43.0)$ & $42(4.2)$ & $527(52.8)$ & Score $5.3 \pm 1.11-7$ & \\
\hline Patients with chronic diseases & $10(1.0)$ & $26(2.6)$ & $963(96.4)$ & & \\
\hline Pregnant females & $44(4.4)$ & $118(11.8)$ & $837(83.8)$ & & \\
\hline Children & $381(38.1)$ & $126(12.6)$ & $492(49.2)$ & & \\
\hline Older people & $8(0.8)$ & $6(0.6)$ & $985(98.5)$ & Score $\%=76.1 \pm 15.2$ & \\
\hline Healthcare workers (HCWs) & $12(1.2)$ & $20(2.0)$ & $967(96.8)$ & & \\
\hline Smokers & $65(6.5)$ & $188(18.8)$ & $746(74.7)$ & & \\
\hline \multicolumn{6}{|l|}{ Knowledge about the preventive measures } \\
\hline Hand washing with soap and water & $4(0.4)$ & $0(0.0)$ & $995(99.6)$ & Score $=8.9 \pm 0.27-9$ & \\
\hline Using tissue during coughing or sneezing & $4(0.4)$ & $4(0.4)$ & $991(99.2)$ & & \\
\hline Cough etiquette & $16(1.6)$ & $26(2.6)$ & $957(95.8)$ & & \\
\hline Avoid touching eyes, nose and mouth with hands & -- & $4(0.4)$ & $995(99.6)$ & & \\
\hline Avoid direct contact with cases & -- & $6(0.6)$ & $993(99.4)$ & Score $\%=99.2 \pm 2.3$ & \\
\hline Wearing masks in crowded places & -- & $0(0.0)$ & $999(100.0)$ & & \\
\hline Keep personal hygiene & $12(1.2)$ & $6(0.6)$ & $981(98.2)$ & & \\
\hline Social distancing $(2 \mathrm{~m})$ & $8(0.8)$ & $0(0.0)$ & $991(99.2$ & & \\
\hline Cleaning and disinfection of groceries & $8(0.8)$ & $0(0.0)$ & 991 (99.2) & & \\
\hline
\end{tabular}


Assessment of attitude toward COVID-19 infection; (Table 3); generally, the majority of the participants had a positive attitude toward the inquired preventive measures items with a mean $14.5 \pm 3.2$. $943(94.4 \%)$ agreed that COVID-19 is curable, 989 $(99.0 \%)$ believed that Lockdown measures designed by the Egyptian government to reduce transmission of infection are essential, and 954 (95.5\%) agreed that the isolation of COVID-19 cases at specialized hospitals is essential, but only 329 (32.9\%) believed that Egyptian's health awareness level is satisfactory.

Table 2: The level of knowledge among studied participants

\begin{tabular}{ll}
\hline The levels of knowledge & $\mathrm{F}(\%)$ \\
\hline Low level of knowledge $<60 \%$ & $123(12.3)$ \\
Moderate level of knowledge $60<80$ & $348(34.8)$ \\
High level of knowledge $80-100 \%$ & $528(52.8)$ \\
\hline
\end{tabular}

Assessment of perceptions toward COVID-19 infection; (Table 4); 990 (99.0\%) perceived themselves as susceptible, and 925 (92.6\%) perceived severity of the disease. On the other hand, as a perceived benefit

Table 3: The attitude of among the participants toward COVID-19 infection

\begin{tabular}{llll}
\hline Participants attitudes & Disagree & Borderline & Agree \\
\hline $\begin{array}{l}\text { Attitude towards the infection } \\
\quad \text { COVID-19 infection is a curable }\end{array}$ & $28(2.8)$ & $48(4.8)$ & $923(92.3)$ \\
$\begin{array}{l}\text { Attitude toward prevention and control of } \\
\text { spread of infection }\end{array}$ & & & \\
$\quad$ Lockdown measures by the authorities \\
$\begin{array}{l}\text { are essential to prevent spread of the } \\
\text { infection }\end{array}$ & $8(0.8)$ & $18(1.8)$ & $973(97.3)$ \\
$\begin{array}{l}\text { Isolation of COVID 19 cases at } \\
\text { specialized hospitals is essential }\end{array}$ & $37(3.7)$ & $8(0.8)$ & $954(95.5)$ \\
$\quad \begin{array}{l}\text { Egyptian's health awareness about the } \\
\text { COVID-19 is satisfactory }\end{array}$ & $616(61.7)$ & $54(5.4)$ & $329(32.9)$ \\
\hline
\end{tabular}

from preventive interventions; 973 (97.4\%) believed that early detection and management will improve the outcome, and 989 (99.0\%) stated that following the preventive measures, decrease the risk of infection.

Table 4: The Health Belief Model among the studied participants

\begin{tabular}{|c|c|c|c|}
\hline Participants perceptions (health belief model) & Disagree & Borderline & Agree \\
\hline \multicolumn{4}{|l|}{ Perceived susceptibility } \\
\hline Perceived susceptibility of infection & $2(0.2)$ & $8(0.8)$ & $990(99.0)$ \\
\hline $\begin{array}{l}\text { Why you perceive yourself as susceptible } \\
\text { person } \mathrm{F}(\%)\end{array}$ & $84(8.4)$ & $304(30.4)$ & $611(61.2$ \\
\hline \multicolumn{4}{|l|}{$\begin{array}{l}\text { Everyone is susceptible as going } \\
\text { outdoors }=760(76.1)\end{array}$} \\
\hline \multicolumn{4}{|l|}{ Coming from abroad=32 (3.2) } \\
\hline \multicolumn{4}{|l|}{$\begin{array}{l}\text { Contact with COVID-19 positive } \\
\text { case }=20(0.2)\end{array}$} \\
\hline \multicolumn{4}{|l|}{ Contact with travelers from abroad=42 (4.2) } \\
\hline \multicolumn{4}{|l|}{ Had chronic diseases=44 (4.4) } \\
\hline \multirow{2}{*}{\multicolumn{4}{|c|}{$\begin{array}{l}\text { Smoker }=40(4.4) \\
\text { Perceived severity }\end{array}$}} \\
\hline & & & \\
\hline COVID-19 infection is a serious disease. & $60(6.0)$ & $14(1.4)$ & $925(92.6)$ \\
\hline \multicolumn{4}{|l|}{ COVID-19) Perceived benefits. } \\
\hline $\begin{array}{l}\text { Early detection of COVID-19 can improve } \\
\text { the outcome }\end{array}$ & $24(2.4)$ & $32(3.2)$ & $943(94.4)$ \\
\hline $\begin{array}{l}\text { Follow preventive measures decrease the } \\
\text { risk of exposure to infection }\end{array}$ & $2(0.2)$ & $8(0.8)$ & $989(99.0)$ \\
\hline \multicolumn{4}{|l|}{ Perceived barriers } \\
\hline Economic burden & $357(35.7)$ & & \\
\hline $\begin{array}{l}\text { Lack of commitment of other community } \\
\text { members }\end{array}$ & $467(46.7)$ & & \\
\hline Dislike using face masks & $139(13.9)$ & & \\
\hline Going to work is necessary & $297(29.7)$ & & \\
\hline Expensive masks & $266(26.6)$ & & \\
\hline Expensive disinfectant & $438(43.8)$ & & \\
\hline Unavailable disinfectant & $156(15.6)$ & & \\
\hline Unavailable soap & $16(0.16)$ & & \\
\hline Embarrassing on wearing masks in public & $51(5.1)$ & & \\
\hline Cannot tolerate mask in hot weather & $405(40.5)$ & & \\
\hline
\end{tabular}

Practices of preventive measures toward COVID 19; 785 (78.5\%) of participants were classified as poor practice. The mean total practice score $52.7 \%$ and $9.6 \%$ SD (Table 6).

As regard daily activities, most of the respondents, 920 (92.1\%), always safely dispose tissues, $886(88.7 \%)$ washing their hands with soap and water, $857(85.8 \%)$ Wearing masks in crowded places, and $810(81.8 \%)$ practicing cough etiquette in absence of tissue, while only $639(64.0 \%)$ always used hand sanitizers.

As regard their preventive measures practices during the past 2 weeks, most of people always maintained personal hygiene 947 (94.8\%), about $88 \%$ avoided travelling to infected areas and eating in restaurants, $862(86.3 \%)$ staying indoor and going outdoor for necessity, while only $333(33.3 \%)$ practicing regular physical activity (Table 5 ).

The total knowledge score was significantly higher among highly educated, females, in rural areas, married and governmental workers, while higher educational level, married females, smokers, absence of chronic diseases, and governmental workers were significantly associated with higher practice scores $(p<0.05)$ (Table 7).

There was a statistical significant direct correlation between the total practice score and the total knowledge score about COVID-19 symptoms, mode of transmission, preventive measurements, and the total knowledge score (Table 8).

\section{Discussion}

The COVID-19 pandemic is a major public health problem in Africa including Egypt [16]. With the absence of an effective vaccine or approved treatment for COVID-19, current control measures are directed toward community education on disease and preventive measures to decrease the disease burden and interrupt the spread of the virus so this study assessed the KAPP toward COVID-19 preventive measures among inhabitants of Egyptians as a key to effective containment.

The findings showed that $80.9 \%$ of the respondents have adequate knowledge aboutCOVID-19 infection that corroborates with Ngwewondo et al. [17] findings which recorded a knowledge score of $84.2 \%$ in Cameroon, and the $83 \%$ overall knowledge percentage in India. However, this finding is higher than that the study in Northwest Ethiopia [15] and that conducted in Buea, Cameroon [18] and is the $90 \%$ reported \% among Chinese [19] and Iran Population. However, most of participants were educated and had an academic degree [14]

Regarding the knowledge about transmission and risky groups $(54.3 \%$ and $76.1 \%)$, these results 
Table 5: The practice of preventive measures among studied participants

\begin{tabular}{|c|c|c|c|c|}
\hline The practice of preventive measures & No $=0$ & Sometimes $=1$ & Always $=2$ & The total \\
\hline Daily activity & & & & Mean \pm SD \\
\hline Washing the hands with soap and water & $(0.2)$ & $111(11.1)$ & $886(88.7)$ & Range The total score $=16.8 \pm 3.6(0-16)$ \\
\hline Using hand sanitizers & $48(4.8)$ & $312(31.2)$ & $639(64.0)$ & \\
\hline Using tissue during coughing or sneezing & $23(2.3)$ & $141(14.1)$ & $835(83.6)$ & \\
\hline Safe disposal of tissues & $16(1.6)$ & $63(6.3)$ & $920(92.1)$ & \\
\hline Cough technique in absence of tissue & $36(3.6)$ & $153(15.3)$ & $810(81.8)$ & \\
\hline Wearing masks in crowded places & $50(5.0)$ & $92(9.2)$ & $857(85.8)$ & \\
\hline \multicolumn{5}{|l|}{ Practices during the previous 2 weeks } \\
\hline Avoiding travelling to infected areas & $28(2.2)$ & $88(8.8)$ & $883(88.4)$ & The percentage of the total practice $=52.7 \pm 9.6(0-92.5)$ \\
\hline Avoiding eating in restaurants & $32(3.2)$ & $86(8.6)$ & $881(88.2)$ & \\
\hline Avoiding crowded places & $28(2.8)$ & $180(18.0)$ & 791 (79.2) & \\
\hline Staying indoor and going outdoor for necessity & $52(5.2)$ & $85(8.5)$ & $862(86.3)$ & \\
\hline Avoiding going to school, college or work & $120(12.0$ & $160(16.0)$ & $719(72.0)$ & \\
\hline Avoiding shaking hands & $53(5.3)$ & $232(23.2)$ & $714(71.5)$ & \\
\hline Avoiding public transportation methods & $83(8.3)$ & $181(18.1)$ & $735(73.6)$ & \\
\hline Proper personal hygiene & $8(0.8)$ & $44(4.4)$ & $947(94.8)$ & \\
\hline Eating balanced food & $45(4.5)$ & $308(30.8)$ & $646(64.6)$ & \\
\hline Practicing regular physical activity & $216(21.6)$ & $450(45.0)$ & $333(33.3)$ & \\
\hline
\end{tabular}

SD: Standard deviation

come in accordance with a study by Ngo Bibaa et al. [20] who found that the majority of participants $56.2 \%$ had moderate level of knowledge about the modes of transmission of the disease and risky groups which is still a lower than other parts of knowledge about the disease.

Table 6: The level of preventive measurement practice and the changes in the frequency of hand washing during the pandemic

\begin{tabular}{lll}
\hline The level of preventive measurement practice & $\mathrm{F}$ & $\%$ \\
\hline Poor practice<60 & 785 & 78.5 \\
Moderate level practice $60<80$ & 214 & 21.4 \\
Good practice level $80-100$ & 0 & 0.0 \\
\hline
\end{tabular}

It was observed that, the total knowledge score was significantly higher among highly educated, females, in rural areas, married, and governmental workers this finding corroborates that of [18]. Female total knowledge score $(26.1 \pm 2.3)$ tended to be more knowledgeable than males'. Similar findings were observed by Akalu et al. [15]. Governmental $(26.7 \pm 2.1)$ and private setting workers $(25.8 \pm 2.1)$ demonstrated significantly higher levels of knowledge than students and farmers this explained by that the level of education attained significantly increases the total knowledge scores as they at least had secondary level of education or above whereas most of the students and farmers were less educated. Our findings are in line with similar studies Nigeria [21], and Bangladesh [22]. Lower knowledge scores about the modes of transmission and risk groups (54.3\% and $76.1 \%$ ), respectively, which is similar to the results reported by Erfani et al. in Iran [14].

As regard the knowledge gap between different items among Egyptians it was reported to be related to disease transmission which was reported to be $54.3 \pm 14.5 \%$, as some believed that the novel coronavirus can be transmitted to people by many modes of transmission. This observation was, however, higher when compared to Ethiopia [15], [23]. This discrepancy might be due to the differences in the time of data collection and the used assessment tool.

The most popular sources of information about COVID-19 infection among Egyptians were in order social media (Facebook, WhatsApp, and twitter) $(64.5 \%)$, followed by international and governmental official websites (12.8\%), Family members (12.4\%), and (TV and radio) (6\%). This comes in agreement with the results by Abdelhafiz et al. [9] who reported that social media especially Facebook were the most common source of knowledge among the studied group in Egypt. Furthermore, this study results were lower than that reported by an Ethiopian study (Hager et al.) where the internet (social media platforms- 84\%) and TV $(44 \%)$ were the main source of information for the participants. But that inconsistent with the results of a study in in Syria where The most common sources of information were TV (66.4\%), followed by government officials $(38.7 \%)$, Facebook $(34.8 \%)$, health workers $(31.4 \%)$, websites $(23.8 \%)$, and family and friends (43.3\%) [23]. Social media platforms had proved to be helpful for population to adapt to the physical social restraints during the COVID-19 compulsory lockdown in and Egypt.

Regarding attitudes of the participants, they showed a positive general attitude toward the preventive measures taken by the government, as $99 \%$ of the them agreed that lockdown measures by the Egyptian authorities are essential to prevent spread of the infection, this comes in accordance with an Iranian study where the majority of participants agreed with having quarantine, locking down cities, restricting travel, and closing educational centers and religious cites $(96 \%, 96.8 \%, 99.3 \%$, and $98.5 \%$, respectively) [14] but slightly higher than reported by an African study (81\%) [21].

In this study, $99 \%$ of participants perceived themselves at risk to acquire infection; this figure was higher than the percentage among chronic patients in France, which reported to be $63 \%$. This difference may be related to the fact that this study addressed the vulnerability to infection and the French one studied the severity of it [24]. Among those perceived themselves at risk of infection $(76.1 \%)$ of them, reported the cause that, everyone is susceptible as going outdoors, this result was higher than that observed by Tran and Ravaud in France, who found that $(23.7 \%)$ reported to be at risk of infection because they worked outside home, had a household member 
Table 7: The demographic data and its relationship with the knowledge and practice scores

\begin{tabular}{|c|c|c|c|c|c|c|c|}
\hline $\begin{array}{l}\text { Socio-demographic } \\
\text { Variables }\end{array}$ & $\mathrm{F}(\%)$ & Total practice score & $\begin{array}{l}\text { Mode of transmission } \\
\text { knowledge score }\end{array}$ & $\begin{array}{l}\text { Preventive measurements } \\
\text { knowledge score }\end{array}$ & $\begin{array}{l}\text { Risky groups } \\
\text { knowledge score }\end{array}$ & $\begin{array}{l}\text { Symptoms } \\
\text { knowledge score }\end{array}$ & Total knowledge score \\
\hline \multicolumn{8}{|l|}{ Age groups } \\
\hline$<20$ year & $234(23.4)$ & $17.2 \pm 2.4$ & $4.3 \pm 1.2$ & $8.9 \pm 0.2$ & $5.5 \pm 0.9$ & $6.7 \pm 1.7$ & $25.6 \pm 2.2$ \\
\hline $20<40$ year & $628(62.8)$ & $16.7 \pm 3.2$ & $4.4 \pm 1.1$ & $8.9 \pm 0.2$ & $5.3 \pm 1.1$ & $7.2 \pm 1.2$ & $26.0 \pm 2.2$ \\
\hline 40 year or more & $136(13.6)$ & $16.6 \pm 3.2$ & $4.6 \pm 1.2$ & $8.9 \pm 0.1$ & $5.2 \pm 1.1$ & $6.9 \pm 1.7$ & $25.9 \pm 2.7$ \\
\hline$F(p)$ & & $1.9(0.15)$ & $2.8(0.05)$ & $3.96\left(0.02^{*}\right)$ & $3.92\left(0.01^{*}\right)$ & $16.2\left(0.00^{*}\right.$ & $9.21(0.06)$ \\
\hline \multicolumn{8}{|l|}{ Sex } \\
\hline Female & $666(66.7)$ & $17.1 \pm 2.8$ & $4.3 \pm 1.3$ & $8.9 \pm 0.2$ & $5.4 \pm 1.1$ & $7.2 \pm 1.3$ & $26.1 \pm 2.3$ \\
\hline Male & $333(33.3)$ & $16.5 \pm 3.5$ & $4.4 \pm 1.0$ & $8.9 \pm 0.3$ & $5.2 \pm 1.0$ & $6.9 \pm 1.5$ & $25.9 \pm 2.1$ \\
\hline$t(p)$ & & $2.34\left(0.02^{\star}\right)$ & $0.33(0.74)$ & $1.8(0.07)$ & $2.03(0.05)$ & $3.8\left(0.00^{\star}\right)$ & $2.9\left(0.00^{\star}\right)$ \\
\hline \multicolumn{8}{|l|}{ Residence } \\
\hline Urban & $576(57.6)$ & $16.7 \pm 3.1$ & $4.5 \pm 1.2$ & $8.9 \pm 0.17$ & $5.3 \pm 1.0$ & $7.0 \pm 1.5$ & $25.7 \pm 2.2$ \\
\hline Rural & $423(42.3)$ & $17.0 \pm 3.1$ & $4.3 \pm 1.1$ & $8.9 \pm 0.23$ & $5.4 \pm 1.1$ & $7.2 \pm 1.2$ & $26.2 \pm 2.4$ \\
\hline$t(p)$ & & $1.6(0.10)$ & $3.34\left(0.00^{\star}\right)$ & $1.23(0.22)$ & $0.97(0.33)$ & $1.12(0.26)$ & $2.4\left(0.02^{\star}\right)$ \\
\hline \multicolumn{8}{|l|}{ Marital status } \\
\hline Single & $308(30.2)$ & $16.8 \pm 2.8$ & $4.4 \pm 1.1$ & $8.9 \pm 0.3$ & $5.4 \pm 0.9$ & $6.8 \pm 1.6$ & $25.5 \pm 2.3$ \\
\hline Married & 665 (66.5) & $17.3 \pm 2.9$ & $4.8 \pm 0.9$ & $9.0 \pm 0.4$ & $5.3 \pm 1.1$ & $6.6 \pm 1.7$ & $26.1 \pm 2.3$ \\
\hline Others* & $26(2.6)$ & $16.8 \pm 3.1$ & $4.3 \pm 1.2$ & $8.9 \pm 0.15$ & $5.2 \pm 0.9$ & $7.3 \pm 1.2$ & $26.0 \pm 2.5$ \\
\hline$F(p)$ & & $0.29(0.74)$ & $1.77(0.17)$ & $6.55\left(0.00^{\star}\right)$ & $1.02(0.76)$ & $17.4\left(0.00^{*}\right)$ & $14.9\left(0.00^{*}\right)$ \\
\hline \multicolumn{8}{|l|}{ Level of education } \\
\hline $\begin{array}{l}\text { Read and write/ } \\
\text { Primary }\end{array}$ & $52(5.2)$ & $16.8 \pm 1.6$ & $4.4 \pm 1.1$ & $8.9 \pm 0.2$ & $5.2 \pm 1.0$ & $6.8 \pm 1.6$ & $24.9 \pm 2.3$ \\
\hline Secondary/High & $342(34.2)$ & $16.8 \pm 3.2$ & $4.3 \pm 1.2$ & $8.9 \pm 0.2$ & $5.5 \pm 1.03$ & $7.3 \pm 1.3$ & $25.9 \pm 2.3$ \\
\hline University/and above & $605(60.5)$ & $17.3 \pm 2.9$ & $4.8 \pm 0.9$ & 9 & $5.2 \pm 1.1$ & $6.6 \pm 1.7$ & $26.1 \pm 2.3$ \\
\hline$F(p)$ & & $0.57(0.64)$ & $0.39(0.76)$ & $3.42\left(0.02^{*}\right)$ & $1.53(0.22)$ & $6.61\left(0.00^{\star}\right)$ & $5.92\left(0.00^{*}\right)$ \\
\hline \multicolumn{8}{|l|}{ Occupation } \\
\hline Don't work/house wife & $311(31.1)$ & $17.2 \pm 3.1$ & $4.2 \pm 1.1$ & $8.9 \pm 0.2$ & $5.1 \pm 1.1$ & $7.3 \pm 1.2$ & $25.6 \pm 2.3$ \\
\hline Student & $276(27.6)$ & $16.9 \pm 2.6$ & $4.4 \pm 1.1$ & $8.9 \pm 0.3$ & $5.4 \pm 0.9$ & $6.7 \pm 1.6$ & $25.5 \pm 2.3$ \\
\hline Private & 198 (19.8) & $16.4 \pm 3.4$ & $4.5 \pm 1.2$ & $8.9 \pm 0.14$ & $5.2 \pm 1.1$ & $7.0 \pm 1.5$ & $25.8 \pm 2.1$ \\
\hline Governmental & $214(21.4)$ & $16.7 \pm 3.0)$ & $4.6 \pm 1.3$ & $8.9 \pm 0.17$ & $5.5 \pm 1.0$ & $7.4 \pm 1.1$ & $26.7 \pm 2.1$ \\
\hline$F(p)$ & & $3.2\left(0.02^{*}\right)$ & $3.9\left(0.01^{\star}\right)$ & $0.98(0.77)$ & $3.7(0.06)$ & $11.2\left(0.00^{\star}\right)$ & $14.6\left(0.00^{*}\right)$ \\
\hline \multicolumn{8}{|l|}{ Smoking } \\
\hline Non-smoker & $843(89.4)$ & $17.1 \pm 2.8$ & $4.4 \pm 1.2$ & $8.9 \pm 0.2$ & $5.4 \pm 1.1$ & $7.1 \pm 1.4$ & $25.9 \pm 2.3$ \\
\hline Ex-smoker & $36(3.6)$ & $16.1 \pm 4.1$ & $4.3 \pm 0.8$ & $8.9 \pm 0.5$ & $4.7 \pm 0.9$ & $6.8 \pm 1.5$ & $25.2 \pm 1.7$ \\
\hline Smoker & $120(12.0)$ & $15.3 \pm 4.1$ & $4.5 \pm 0.9$ & $8.9 \pm 0.18$ & $5.2 \pm 1.1$ & $7.1 \pm 1.1$ & $25.5 \pm 2.0$ \\
\hline$F(p)$ & & $19.4\left(0.00^{*}\right)$ & $0.17(0.84)$ & $2.86(0.06)$ & $6.83\left(0.02^{*}\right)$ & $0.26(0.76)$ & $2.90(0.06)$ \\
\hline \multicolumn{8}{|l|}{ Had a chronic disease } \\
\hline No & 894 (89.5) & $16.9 \pm 2.9$ & $4.4 \pm 1.2$ & $8.9 \pm 0.2$ & $5.3 \pm 1.1$ & $7.1 \pm 1.4$ & $25.9 \pm 2.3$ \\
\hline Yes & 105 (10.5) & $16.0 \pm 3.7$ & $4.3 \pm 1.0$ & $8.9 \pm 0.1$ & $5.4 \pm 1.2$ & $7.1 \pm 1.3$ & $25.9 \pm 2.3$ \\
\hline$t(p)$ & & $2.99\left(0.00^{\star}\right)$ & $1.05(0.29)$ & $0.05(0.96)$ & $0.18(0.86)$ & $0.02(0.99)$ & $1.02(0.31)$ \\
\hline
\end{tabular}

working outside home or had regular visits from external contacts [24].

Table 8: Correlation between the total practice score and the following knowledge scores

\begin{tabular}{lll}
\hline The total practice score and knowledge scores & $\mathrm{r}$ & $\mathrm{p}$ \\
\hline Symptoms & 0.23 & $0.00^{*}$ \\
Mode of transmission & 0.09 & $0.01^{*}$ \\
Preventive measures & 0.08 & $0.02^{*}$ \\
Knowing risky groups & 0.37 & 0.29 \\
Total knowledge score & 0.19 & $0.00^{*}$ \\
\hline p $<0.05$ there was statistical significant difference. & &
\end{tabular}

About $46.7 \%$ of the studied population complained of lack of commitment of other community members as a barrier toward the preventive measures, this comes in accordance with a study among healthcare providers in Ethiopia, that found almost half $(51.37 \%)$ of participants reported less commitment of the providers as a barrier. Moreover, $70.4 \%$ complained of high costs of masks and disinfectants while 15.76 complained of unavailability of masks and disinfectants. Hence, $86.16 \%$ reported limited access to infection control materials. This was higher than reported by the Ethiopian study as $52.5 \%$ of participants, reported limitation of infection control materials. These differences may be related to the difference in the studied groups, as in the Ethiopian study, the studied group was health-care providers while, in this study, the studied group was the general population [25].

The overall practice of COVID-19 preventive measures was poor among $785(78.5 \%)$ of respondents. This can explain the increase in the number of infected cases in Egypt as, strong preventive measures are the primary line of intervention to minimize the spread of the virus in both health-care settings and the community [26], and the effective management of the pandemic depends primarily on people's adherence to the recommended preventive measures [14].

Most respondents used face masks when going to public gathering and practicing proper hand hygiene as preventive measures in reducing the chances of being infected. This generally indicates willingness of the Egyptians to relevant practices changes in dealing with COVID-19 pandemic. Similar practice toward most preventive measures were earlier reported in China [19]) Egypt [9] and India [27], although there was a reduction in the frequency of using face masks.

Despite a majority of respondents knowing that social distancing is important in COVID-19 prevention, only $32.4 \%$ practiced it. This finding is consistent with a study in Nigeria [14], who believed that the virus can only be transmitted through close contact. Considering barriers against implementation of good practices This is because that this study was conducted at beginning of the pandemic so the practices of the population were not yet well developed and also poor practices may be related to positive attitude towards the disease as $92.3 \%$ of the participants believed that COVID 19 is a curable disease.

Adequate practice was significantly associated with the age groups and occupation w. The higher adequate practice observed among older respondents 
might be to prevent risk of developing severe illnesses. It has generally been observed that older people face significant risk of developing severe illness if they contract the disease due to physiological changes that come with aging and potential underlying health conditions [28].

Although the absence of significant difference between groups in the total knowledge score regarding history of smoking and chronic diseases, there was a significant difference at the total practice score to be significantly higher among participants without chronic diseases and nonsmokers, this finding, may be associated with increased risk of infection, does augur a poor prognosis in patients with COVID-19 [29], [30], [31] so more focus on practices of high risk groups is essential. This can be explained by the fact that people who avoid smoking may have better healthy lifestyle practices than smokers including preventive practices related to COVID 19.

The observed disparity between the level of knowledge, practice, and perceptions in the attached Health Belief Model among the studied participants, might be due to the difference in sociodemographic characteristics, available sources of information, outbreak situation in the studied area, health awareness, routine health practices, and level of participant's worry related to the outbreak, which led to the variation in the application of recommended actions and behaviors to prevent COVID-19. Moreover, the action taken by the government to decrease transmission of COVID-19 might also account for the variation.

There was significant direct association between the total knowledge and the total practice score as the practice and effective adoption of selfprotection measures are largely affected by knowledge, attitudes, and practices (KAP) of the public [21] in accordance with the "KAP theory." The "KAP theory" is a health behavior change theory wherein the change in human behavior is divided into three successive processes, namely, acquisition of right knowledge, generation of attitudes, and adoption of behavior (or practice) [26].

\section{Limitations}

The majority of the study participants were educated with $73 \%$ of the them having a graduate or post-graduate degree. Thus, the study population represented a relatively well-educated and well-to-do section of the community and hence might not be representative of Egyptians. Moreover, the distribution of the survey through the internet allowed only those who can read and have internet access to participate. This represents a major limitation of this study.

\section{Conclusions}

Egyptian participates had good level of knowledge, positive attitudes toward COVID-19 infection and its interventions and, unfortunately poor practices, which were related to presence of several barriers and perceptions that should be considered by the government during planning and implementing interventions that enable better practices.

\section{Recommendations}

(1) Redistribute the results to the policy makers as an up-to-date national study. (2) Community education on preventive measures remains the best control measure to reduce the disease burden and spread. (3) Measures to enhance good preventive practices and reducing barriers should be considered by the government. (4) The demographic characters associated with KAP could be the cornerstone in directing policy-makers to target the health education campaigns to the suitable target groups. (5) Furthermore, comprehensive studies.

\section{Authors' Contribution}

DIO conceived the study, designed the data collection tool, data acquisition, and wrote the proposal. Statistical analysis, data interpretation, manuscript preparation, and drafting by SAA. The manuscript was written, reviewed, and edited by DIO and SAA.

\section{Acknowledgments}

Our appreciation goes to all participants who collaborated to the success of this study.

\section{Availability of Data and Materials}

The datasets used and analyzed during the current study are available from the corresponding author on reasonable request. 


\section{Ethical considerations}

The objectives of the study, voluntary involvement or withdrawal, and confidentiality of the data were clarified to the participants before taking agreement on involvement. All these data were appended with the electronic form of the questionnaire.

\section{References}

1. Wu F, Zhao S, Yu B, Chen YM, Wang W, Song ZG. A new coronavirus associated with human respiratory disease in China. Nature. 2020;579(7798):265-9.

PMid:32015508

2. Tang D, Tou J, Wang J, Chen Q, Wang W, Huang J. Prevention and control strategies for emergency, limited-term, and elective operations in pediatric surgery during the epidemic period of COVID-19. World J Pediatr Surg. 2020;3(1):e000122. https:// doi.org/10.1136/wjps-2020-000122

3. World Health Organization. Coronavirus Disease (COVID-19) Situation Report-126. Geneva: World Health Organization; 2020. Available from: https://www.who.int/docs/default-source/ coronaviruse/situationreports/20200525-covid-19-sitrep-126. pdf?sfvrsn=887dbd66_2. [Last accessed on 2020 May 25].

4. Cascella M, Rajnik M, Cuomo A, Dulebohn SC, Di Napoli R. Features, Evaluation, and Treatment of Coronavirus (COVID19). Treasure Island, FL: StatPearls Publishing LLC; 2020.

5. World Health Organization, Health Topics, Coronavirus, Symptomes. Available from: https://www.who.int/health-topics/ coronavirus\#tab=tab_3. [Last accessed on 2021 Jan 12].

6. World Health Organization. Considerations for Implementing and Adjusting Public Health and SOCIAL MEASURES in the Context of COVID-19: Interim Guidance, 4 November 2020. Geneva: World Health Organization; 2020. Available from: https://www.apps.who.int/iris/handle/10665/336374.

7. Bruinen de Bruin $Y$, Lequarre AS, McCourt J, Clevestig P, Pigazzani F, Zare Jeddi M. Initial impacts of global risk mitigation measures taken during the combatting of the COVID-19 pandemic. Saf Sci. 2020;128:104773. https://doi.org/10.1016/j. ssci.2020.104773

PMid:32296266

8. The Central Agency for Public Mobilization and Statistics Website; 2020. Available from: https://www.capmas.gov.eg/ Pages/populationClock.aspx\#. [Last accessed on 2020 Apr 04].

9. Abdelhafiz AS, Mohammed Z, Ibrahim ME, Ziady HH, Alorabi M, Ayyad $\mathrm{M}$, et al. Knowledge, perceptions, and attitude of Egyptians towards the novel coronavirus disease (COVID-19). J Community Health. 2020;45(5):881-90. https://doi.org/10.1007/ s10900-020-00827-7

PMid:32318986

10. Hager E, Odetokun IA, Bolarinwa O, Zainab A, Okechukwu O, Al-Mustapha Al. Knowledge, attitude, and perceptions towards the 2019 coronavirus pandemic: A bi-national survey in Africa. PLoS One. 2020;15(7):e0236918. https://doi.org/10.1371/ journal.pone. 0236918

PMid:32726340

11. Presidency of the Council of Ministers, Report of the Egyptian Government Efforts Facing Novel Corona Virus Pandemic. Available from: https://www.cutt.us/hCgLd. [Last accessed on 2021 Jan 13]

12. Egyptian Government's Anti-virus Plan Met with Mixed Reactions; 2020. Available from: https://www.almonitor. com/pulse/originals/2020/03/egypt-coronavirus-curfew-sisimeasures-protests.html. [Last accessed on 2020 Apr 04].

13. WHO Courses. Emerging Respiratory Viruses, including COVID-19: Methods for Detection, Prevention, Response, and Control. Available from: https://www.openwho.org/courses/ introductionto-ncov. [Last accessed on 2020 Feb 10].

14. Erfani A, Shahriarirad R, Ranjbar K, Mirahmadizadeh A Moghadami M. Knowledge, attitude and practice toward the novel coronavirus (COVID-19) outbreak: A population-based survey in Iran. Bull World Health Organ. 2020. http://dx.doi. org/10.2471/BLT.20.256651

15. Akalu $Y$, Ayelign B, Molla MD. Knowledge, attitude and practice towards COVID-19 among chronic disease patients at Addis Zemen hospital, Northwest Ethiopia. Infect Drug Resist. 2020;13:1949-60. https://doi.org/10.2147/idr.s258736 PMid:32612371

16. World Health Organization. Time-line COVID-2019. Available: https://www.who.int/news-room/detail/27-04-2020-whotimeline---covid-19 [Last accessed on 2020 Jun 25].

17. Ngwewondo A, Nkengazong L, Ambe LA, Ebogo JT, Mba FM, Goni HO, et al. Knowledge, attitudes, practices of/towards COVID 19 preventive measures and symptoms: A crosssectional study during the exponential rise of the outbreak in Cameroon. PLoS Negl Trop Dis. 2020;14(9):e0008700. https:// doi.org/10.1371/journal.pntd.0008700 PMid:32886678

18. Tendongfor N, Forlemu VM, Seraphine NE, Amana BT, Kouam TD, Lambou FV, et al. COVID-19 knowledge, attitudes and practices in a conflict affected area of the South West Region of Cameroon. Pan Africa Med J. 2020;35(2):34. PMid:33623559

19. Zhong BL, Luo W, Li HM, Zhang QQ, Liu XG, Li WT, et al. Knowledge, attitudes, and practices towards COVID-19 among Chinese residents during the rapid rise period of the COVID-19 outbreak: A quick online cross-sectional survey. Int J Biol Sci. 2020;16(10):1745-52. https://doi.org/10.7150/ijbs.45221 PMid:32226294

20. Reuben RC, Danladi MMA, Saleh DA, Ejembi PE. Knowledge, attitudes and practices towards COVID-19: An epidemiological survey in North-Central Nigeria. J Community Health. 2020;2020:1-14. http://dx.doi.org/10.1007/s10900-020-00881-1 PMid:32638198

21. Singh AK, Gupta R, Ghosh A, Misra A. Diabetes in COVID19: Prevalence, pathophysiology, prognosis and practical considerations. Diabetes Metab Syndr. 2020;14(4):303-10. https://doi.org/10.1016/j.dsx.2020.04.004 PMid:32298981

22. Ferdous MZ, Islam MS, Sikder MT, Mosaddek AS, ZegarraValdivia JA, Gozal D. Knowledge, attitude, and practice regarding COVID-19 outbreak in Bangladesh: An online-based cross-sectional study. PLoS One. 2020;15(10):e0239254. https://doi.org/10.1371/journal.pone.0239254

PMid:33035219

23. International Federation of Red Cross and Red Crescent Societies. Knowledge, Attitudes and Practices (KAP) Assessment on COVID-19 - Community Based Migration Programme. Geneva: International Federation of Red Cross and Red Crescent Societies; 2020. https://doi. org/10.1163/2210-7975_hrd-9813-2015012

24. Tran VT, Ravaud P. COVID-19-related perceptions, context and attitudes of adults with chronic conditions: Results from a cross-sectional survey nested in the ComPaRe e-cohort. PLoS One. 2020;15(8):e0237296. https://doi.org/10.1371/journal. pone. 0237296

PMid:32760127 
25. Birihane BM, Bayih WA, Alemu AY, Belay DM. Perceived barriers and preventive measures of COVID-19 among healthcare providers in Debretabor, North Central Ethiopia, 2020. Risk Manag Healthc Policy. 2020;13:2699-706. https:// doi.org/10.2147/rmhp.s287772

PMid:33244283

26. Pal R, Bhansali A. COVID-19, diabetes mellitus and ACE2: The conundrum. Diabetes Res Clin Pract. 2020;162:108132. https:// doi.org/10.1016/j.diabres.2020.108132

PMid:32234504

27. Agarwal P, Imtiyaz B, Raunaq MS, Jamwal C. Knowledge, Attitudes, and Practices (KAP) about COVID-19 among Indian Population: A Cross-sectional Study (July 22, 2020); 2020. Available from: https://www.ssrn.com/abstract $=3658195$ or http://dx.doi.org/10.2139/ssrn.3658195.

28. World Health Organization. WHO Delivers Advice and Support for Older People during COVID-19. https://doi.org/10.7748/ nop.32.5.5.s1

29. Li JY, You Z, Wang Q, Zhou ZJ, Qiu Y, Luo R, et al. The epidemic of 2019-novel-coronavirus (2019-nCoV) pneumonia and insights for emerging infectious diseases in the future. Microbes Infect. 2020;22(2):80-5. https://doi.org/10.1016/j.micinf.2020.02.002 PMid:32087334

30. Ngo Bibaa LO. Primary health care beyond COVID-19: Dealing with the pandemic in Cameroon. BJGP Open. 2020;4:bjgpopen20X101113. http://doi.org/10.3399/ bjgpopen20X101113

PMid:32900705

31. Fadini GP, Morieri ML, Longato E, Avogaro A. Prevalence and impact of diabetes among people infected with SARS-CoV-2. J Endocrinol Invest. 2020;43(6):867-9. https://doi.org/10.1007/ s40618-020-01236-2

PMid:32222956 


\section{Appendix}

The questionnaire of KPAP study: (Knowledge, perceptions, attitude, and practices)

Age - sex - residence - marital statuseducation- occupation- smoking history- presence of chronic disease

\section{I.P}

Symptoms of novel coronavirus infection

- $\quad$ Fever
Dry cough
- $\quad$ ifficulty of breathing (dyspnea)
- $\quad$ Sore throat muscle pain
Gastrointestinal disturbances (vomiting or
diarrhea)
Absence of apparent symptoms.

Modes of transmission

- $\quad$ Droplet infection (during coughing or sneezing)

- $\quad$ Contact with contaminated surfaces

- Blood transfusion

- $\quad$ Dealing with or eating wild animals

- $\quad$ Eating contaminated food

- $\quad$ Drinking contaminated water

- $\quad$ Airborne infection

- $\quad$ Direct contact with cases.

High risk groups

- $\quad$ All community members

- Patients with chronic disease

- $\quad$ Pregnant females

- $\quad$ Older persons

- Children

- Health care providers

- Smokers.

Preventive measures for novel corona virus infection

- $\quad$ Frequent washing the hands with soap and water

- $\quad$ Using tissue during coughing or sneezin

- Using upper hand during coughing or sneezing in absence of tissue

- $\quad$ Avoid touching eyes, nose and mouth with hands

- $\quad$ Avoid direct contact with cases

- Wearing masks in crowded places

- Keep personal hygiene

- $\quad$ Social distancing $(2 \mathrm{~m})$

- $\quad$ Cleaning and disinfection of groceries.

\section{Attitudes and perceptions}

Novel corona virus infection is severing (perceived severity).
Early detection and management will improve the chances of cure (attitude towards intervention).

Novel corona virus infection can be treated at home (attitude towards the disease).

Novel corona virus infection is curable (attitude towards the disease).

Health awareness about the disease in Egypt is satisfactory (attitude towards intervention).

Lockdown measures in infected areas are essential for prevention and control of spread of infection (Attitude towards intervention).

Isolation of cases at specialized hospitals is essential (attitude towards intervention) susceptibility)

Are you at risk of infection?? (perceived person?

Why you perceive yourself as susceptible

The practice

Routine practices (daily life practices)

- $\quad$ Frequent washing the hands with soap and water

- Disinfection of hands.

- Using tissue during coughing or sneezing.

- $\quad$ Safe disposal of tissues.

- Using upper hand during coughing or sneezing in absence of tissue.

- Wearing masks in crowded places.

weeks.

Other preventive practices during the last 2

Avoiding travelling to infected areas.

Avoiding eating in restaurants.

Avoiding crowded places.

Staying indoor and going outdoor for necessity.

Avoiding going to school, college or work.

Avoiding shaking hands.

Avoiding public transportation methods.

Personal cleanliness.

Eating balanced food.

Practicing regular physical activity.

To what extent novel corona virus pandemic has affected your hand washing habits?

Obstacles during following the preventive measures (perceived barriers).

Basic sources of knowledge about the disease. 